\title{
INTERAKSI SOSIAL ANTARUMAT BERAGAMA DI DESA NANIA, KOTA AMBON, PROVINSI MALUKU
}

\author{
Alce Albartin Sapulette \\ Dosen Institut Agama Kristen Negeri Ambon \\ *)E-mail : sapulettealce@gmail.com
}

\begin{abstract}
Religious diversity has become a necessity for the people of Indonesia, including in Maluku Province. The inter-religious social relation is created harmoniously even though in 1999 there had been a conflict in this province. However, the people of Maluku, especially in Nania village, continue to create inter-religious social relations. The relation is proven through the interaction between fellow religious people. According to Emile Durkheim, social interaction is a social fact which in essence will result a social solidarity. Solidarity emphasizes on the relations between individuals and groups and underlies the common attachment in life which is supported by moral values and beliefs in the society. The real manifestation of the relationship will produce an emotional experience, thus strengthening the relationship between them. The Durkheim's view became evident in the social life of the people in Nania Village, Ambon City.
\end{abstract}

Keywords: diversity, relations, social, religion, Ambon city, Maluku.

\section{Pendahuluan}

Kemajemukan masyarakat Indonesia adalah kenyataan objektif, yang mana dalam konteks kehidupan keberagamaan nampak keperbedaan agama yang dimiliki. Kemajemukan beragama dalam konteks sosial adalah salah satu realitas yang selalu diwarnai dengan pola-pola interaksi sosial yang dibangun dan sifatnya dinamis sesuai dengan perkembangan zaman. Pada zaman modern sekarang ini, masalah pluralitas agama lebih dititikberatkan pada masalah pemahaman seorang penganut agama atas dogma agama yang dianutnya. Kebanyakan tujuan pokok seseorang beragama adalah penganutnya mendapat pegangan melalui agama yang dianutnya untuk memperoleh kesempurnaan dan keselamatan. Namun, untuk mencapai kesempurnaan tersebut, tidaklah segampang membalik telapak tangan karena manusia tidak hidup dalam dunia homogenitas tetapi manusia hidup dalam kebersamaan yang majemuk.

Manusia sebagai makhluk sosial tidak dapat hidup seorang diri melainkan hidup berdampingan dengan orang lain dengan tujuan untuk saling membantu dalam memenuhi kebutuhan hidupnya. ${ }^{1}$ Pola hidup berdampingan dalam konteks sosial disebut dengan istilah hidup bertetangga. Hidup bertetangga adalah salah satu bentuk pola hidup sosial yang mana seorang individu atau masyarakat dapat beradaptasi, berinteraksi dan mengembangkan kepribadiannya dalam membangun hubungan dengan orang lain.

Dalam menata kehidupan bertetangga, setiap keluarga berkeinginan agar tiap anggota keluarga dapat menikmati kehidupan yang bahagia dan sejahtera dengan anggota masyarakat lain yang ada di sekitar lingkungan tempat tinggalnya. Keluarga yang sejahtera bukan saja berarti aman, nyaman, sentosa dan makmur dalam kehidupan keluarganya saja, namun kesejahteraan itu dapat menyangkut dengan suatu keadaan rasa aman dan tidak kurang suatu apapun dalam lingkungan sosial sesuai ukuran kelompok masing-masing dan pada zamannya masingmasing. $^{2}$

${ }^{1}$ George C. Boeree. Psikologi Sosial. 2010. Jogjakarta : Prismas Sophie. H.1.

${ }^{2}$ Drajat C.W. Pedidikan Kesejahteraan Keluarga. 1997. Jakarta: Depdikbud. H.5 
Konteks hidup bertetangga mempunyai fungsi yang tidak hanya terbatas pada sikap saling menegur atau menyapa satu sama lain jika bertemu, tetapi dalam konteks sosial secara totalitas dapat bekerjasama dalam menolong sesama yang membutuhkan pertolongan misalnya membangun rumah, memberi makan, pakaian, dan lain-lain bagi tetangga yang membutuhkan, menolong tetangga baik suka maupun duka, menghargai agama lain yang sedang beribadah, dan lain-lain. Setiap individu dalam lingkungan sosial dibutuhkan dan saling membutuhkan satu sama lain, supaya mereka dapat hidup lebih senang dan tenang. Hubungan ketergantungan di dalam keluarga dan masyarakat ini yang kemudian terbentuknya sebuah sistem dalam suatu komunitas, yang mana pola interaksinya disebut hidup bertetangga.

Kehidupan bertetangga harus menjalankan perannya secara terintegrasi dalam suatu kesatuan sebagai sistem yang saling mempengaruhi. Setiap indivudu yang membangun hidup bertetangga perlu untuk memahami dan merealisasikan faktor-faktor interaksi sosial secara baik dan benar, agar tidak terjadi konflik dalam lingkungan hidup bertetangga.

Pola kehidupan di Desa Nania Kecamatan Teluk Ambon Baguala, sangat unik. Dikatakan unik karena di Desa tersebut, terbentuk suatu kehidupan tetangga yang memiliki kepelbagaian agama sehingga pola kehidupan yang terjadi di Desa tersebut adalah kehidupan antar umat beragama. Pola interaksi sosial antar umat beragama yang dulu dibangun secara baik, rukun dan harmonis. Namun, pasca kerusuhan tahun 1999, keharmonisan dan kerukunan tersebut secara perlahan-lahan menjadi pudar akibat adanya sentimen antar agama sebagai imbas dari anggota keluarga yang korban dari kerusuhan baik dari Agama Islam, Kristen
Protestan maupun Khatolik. Dendam yang masih terpendam itu membuat sikap dan perilaku dari anggota tetangga menjadi berubah. Ketidakharmonisan ini hanya terjadi antar umat beragama Islam, Kristen Protestan dan Kristen Khatolik. Perubahan sikap ini nampak pada hal-hal seperti sikap (masuk keluar rumah) antar tetangga sudah tidak lagi dilakukan, sikap kerjasama dalam rangka toleransi dalam hari-hari besar keagamaan tidak lagi dilaksanakan seperti membuat kue bersama bagi ibu-ibu dan perempuan muda, membagi kue pada hari raya seperti Natal dan Idul Fitri tidak lagi dilakukan, kerja bakti sosial antar umat beragama tidak lagi dilakukan (kalaupun dilakukan tidak terlalu kelihatan harmonis), serta sapa menyapa terjadi saat bertemu dan hanya dilakukan oleh tetangga yang berdekatan rumah saja dan itupun yang sudah saling kenal. Karena masing-masin anggota keluarga mempertahankan dan memegang prinsip agama yang dianutnya. Dengan demikian, ada masalah yang terjadi didalam interaksi antar umat beragama di Desa Nania.

Akibat dari prinsip beragama yang dipegang cukup kuat membuat interaksi sosial antar umat beragama tidak berjalan sesuai dengan apa yang diharapkan. Hal ini nampak juga ketika ibadah yang dijalankan oleh agama lain seperti Agama Kristen Protestan dan Khatolik, seringkali yang beragama Islam berteriak (membuat keributan secara disengaja) disamping gedung ibadah. Hal ini mengindikasikan bahwa penganut agama lain yang berbeda agama tidak memiliki sikap toleransi misalnya menerima ibadah tersebut dengan sikap toleransi. Fakta sosial seperti ini merupakan masalah dalam interaksi sosial antar agama di Desa Nania.

Kenyataan sosial ini pada akhirnya membawa dampak negatif bagi pertumbuhan individu dalam lingkungan sosial khususnya 
interaksi sosial yang akan dibangun. Individu yang mengalami kenyataan sosial di Desa Nania bukan saja mengalami permasalahan sosial saja tetapi juga masalah psikis. Hal ini terbukti dari banyak masyarakat yang tidak tenang ketika hidup berdampingan dengan orang yang berbeda agama. Banyak anggota keluarga dari masyarakat Desa Nania mengalami trauma akan masa kerusuhan yang dulu terjadi. Karena trauma ini, banyak masyarakat Nania yang menjadi stress dan akhirnya mereka terperangkap pada kecurigaan antara satu dan yang lain yang bermuara pada tindakan saling mengganggu dan mengejek. Hal ini terkadang menjadi bumerang bagi masyarakat Desa Nania dimana pernah menjadi pemicu perkelahian antar keluarga yang berbeda agama. Tindakan beberapa orang yang dinilai secara ekstrem dalam masyarakat Desa Nania sangat mempengaruhi kehidupan masyarakat Desa Nania karena pola pemikiran masyarakat Desa Nania masih terperangkap pada pikiran sempit (seperti salah satu ungkapan masyarakat Desa Nania: (kalau dia satu agama dengan beta (saya), maka beta (saya) adalah saudaranya dan beta (saya) lebih percaya dia daripada orang lain).

Permasalahan lain yang ditemukan yaitu ada keluarga yang mengalami dendam karena keluarga mereka menjadi korban pembunuhan dalam kerusuhan yang terjadi di masa lampau. Hal ini mengakibatkan anggota keluarga tersebut membuat sikap antipati terhadap tetangga-tetangga mereka yang berbeda agama. Bahayanya, keluarga ini sering menjadi penghasut bagi tetanggatetangga lain yang satu agama dengan mereka. Hasutan yang dimaksud ialah keluarga ini mengajak keluarga mereka yang satu agama dengan mereka untuk jangan berteman dengan tetangga yang beda agama karena mereka kafir dan akan mendatangkan kesialan bagi kita. Dengan demikian, dapat dikatakan bahwa kehidupan bertetangga yang terjadi di Desa Nania Ambon adalah kehidupan bermasalah. Permasalahan tersebut bukan saja ditimbulkan dari trauma akan kerusuhan di masa lampau saja, akan tetapi masalah ini juga dipicu oleh tindakan dari masing-masing individu yang membawa dampak pada kehidupan sosial/bertetangga. Hal ini merupakan masalah yang menarik karena permasalahan pada seorang individu mengakibatkan permasalahan untuk suatu kelompok masyarakat atau pada kehidupan bertetangga.

\section{Interaksi Sosial antar Agama}

Melihat hubungan antar agama didunia sekarang ini, sangat jelas bahwa hubungan antar agama dapat diibaratkan seperti bom waktu, yang sekali-kali akan meledak dan menghancurkan. Ini merupakan kenyataan sosial yang sangat memprihatinkan. Kenyataan sosial seperti ini menjadi permasalahan serius dalam menjalani hubungan atau interaksi sosial khususnya antar agama. Untuk melihat permasalahan mengenai kenyataan sosial tersebut, Emile Durkheim memberikan suatu gambaran teori mengenai kenyataan fakta sosial dan solidaritas sosial.

Durkheim dengan pendekatan sosiologinya mengatakan bahwa gejala sosial itu riil dan mempengaruhi kesadaran individu serta perilakunya yang berbeda dari karakteristik psikologis, biologis, atau karakteristik individu yang lainnya. Lebih lagi bahwa gejala itu merupakan fakta yang riil, gejala-gejala tersebut dapat dipelajari dengan metode-metode empirik yang memungkinkan satu ilmu sejati tetang masyarakat dapat dikembangkan. ${ }^{3}$

${ }^{3}$ D. Paul.Johnson. Teori Sosiologi Klasik dan Modern, Jilid I dan II, terj. Robert M.Z. 1964. Lawang, Jakarta: Gramedia.H. 174. 
Durkheim memiliki pandangan yang berbeda dengan para sosiolog-sosiolog sebelumnya. Bagi Emille Durkheim, fakta sosial tidak dapat direduksikan ke fakta individu, melainkan memiliki eksistensi yang independen pada tingkat sosial. Menurutnya, segala usaha untuk menjelaskan gejala sosial akhirnya harus didasarkan pada proposisi-proposisi mengenai perilaku individu. Hal ini berarti bahwa meskipun karakteristik suatu kelompok mungkin lebih dari pada jumlah individu yang meliputi kelompok itu, kelompok tidak dapat ada secara terpisah dari anggota-anggota individualnya. Berdasarkan analisa yang dilakukan oleh Durkheim, didapati bahwa orang tidak bisa langsung mengamati kelompok sebagai suatu benda fisik; orang mengambil kesimpulan mengenai eksistensinya dengan mengamati kegiatan dan interaksi individu dengan sesamanya dalam waktu tertentu, atau dengan belajar dari individu-individu yang terlibat yang menerima kelompok itu sebagai sesuatu yang riil dan berhubungan dengan kelompok itu. ${ }^{4}$

Untuk membuktikan gejala-gejala sosial itu berbeda dengan gejala yang benarbenar individual, Durkheim mengemukakan dengan tegas tiga karakteristik yang berbeda dan karakteristik ini disebut oleh Durkheim sebagai karakteristik fakta sosial. Pertama, gejala sosial bersifat eksternal terhadap individu. Setelah memberikan pembuktian mengenai fakta sosial (bahasa, sistem moneter, norma-norma profesional, dll), Durkheim menegaskan bahwa "ini merupakan cara bertindak, berfikir, dan berperasaan yang memperlihatkan sifat patut dilihat sebagai sesuatu yang berada di luar kesadaran individu". Kedua, bahwa fakta sosial itu memaksa individu. Jelas bagi Durkheim bahwa individu dipaksa, dibimbing, diyakinkan, didorong, atau dengan cara tertentu dipengaruhi oleh berbagai tipe fakta sosial dalam lingkungan sosialnya. Seperti yang Durkheim katakan : "Tipe - tipe perilaku atau berfikir ini mempunyai kekuatan memaksa yang karenanya mereka memaksa individu terlepas dari kemauan individu itu sendiri”. Ini tidak berarti bahwa individu itu harus mengalami paksaan fakta sosial dengan cara yang negatif atau membatasi seperti memaksa seseorang untuk berperilaku yang bertentangan dengan kemauannya. Karakteristik fakta sosial yang ketiga, adalah bahwa fakta itu bersifat umum atau tersebar secara meluas dalam satu masyarakat. Dengan kata lain, fakta sosial itu merupakan milik bersama, bukan sifat individu perorangan. Sifat umumnya ini bukan sekedar hasil dari penjumlahan beberapa fakta individu. Fakta sosial benarbenar bersifat kolektif, dan pengaruhnya terhadap individu merupakan hasil dari sifat kolektifnya ini. Durkheim ingin menegakkan pentingnya tingkat sosial daripada menarik kenyataan sosial dari karakteristik individu. ${ }^{5}$

Dalam buku Rules of Sociological Method, Durkheim menulis: "Fakta sosial adalah setiap cara bertindak, baik tetap maupun tidak, yang bisa menjadi pengaruh atau hambatan eksternal bagi seorang individu." Dalam sudut pandang Durkheim, sosiologi sederhananya adalah 'ilmu dari fakta sosial'. Oleh karena itu, tugas dari para ahli sosiologi adalah mencari hubungan antara fakta-fakta sosial dan menyingkapkan hukum yang berlaku. Setelah hukum dalam struktur sosial ini ditemukan, baru kemudian para ahli sosiologi dapat menentukan apakah suatu masyarakat dalam keadaan 'sehat' atau 'patologis' dan kemudian menyarankan perbaikan yang sesuai. 
Fakta sosial meliputi gejala seperti norma, ideal moral, kepercayaan, kebiasaan, pola berpikir, perasaan dan pendapat umum. Durkheim menggunakan istilah "representatif kolektif" untuk menunjukan gejala ini apabila mereka dimiliki bersama oleh anggota-anggota suatu masyarakat. Durkheim juga mengatakan bahwa fakta sosial harus dijelaskan dalam hubungannya dengan fakta sosial lainnya. Ini adalah asas pokok yang mutlak. ${ }^{6}$

Setelah melihat fakta sosial maka hal selanjutnya akan membahas solidaritas menurut pemikiran Durkheim. Konsep solidaritas sosial merupakan konsep sentral Emille Durkheim dalam mengembangkan teori sosiologi. Durkheim menyatakan bahwa solidaritas sosial merupakan suatu keadaan hubungan antara individu dan atau kelompok yang didasarkan pada perasaan moral dan kepercayaan yang dianut bersama dan diperkuat oleh pengalaman emosional bersama. $^{7}$ Solidaritas menekankan pada keadaan hubungan antar individu dan kelompok dan mendasari keterikatan bersama dalam kehidupan dengan didukung nilai-nilai moral dan kepercayaan yang hidup dalam masyarakat. Wujud nyata dari hubungan bersama akan melahirkan pengalaman emosional, sehingga memperkuat hubungan antar mereka. Menurut Durkheim, berdasarkan hasilnya, solidaritas dapat dibedakan antara solidaritas positif dan solidaritas negatif. Solidaritas negatif tidak menghasilkan integrasi apapun, dan dengan demikian tidak memiliki kekhususan, sedangkan solidaritas positif dapat dibedakan berdasarkan ciri-ciri: Pertama, yang satu mengikat individu pada masyarakat secara langsung, tanpa perantara.

${ }^{6}$ D. Paul. Johnson. Teori Sosiologi Klasik dan Modern, Jilid I dan II, terj. Robert M.Z..H. 174-179.

${ }^{7}$ D. Paul.Johnson. Teori Sosiologi Klasik dan Modern, Jilid I dan II, terj.H. 174-181.
Pada solidaritas positif yang lainnya, individu tergantung dari masyarakat, karena individu tergantung dari bagian-bagian yang membentuk masyarakat tersebut. Kedua, solidaritas positif yang kedua adalah suatu sistem fungsi-fungsi yang berbeda dan khusus, yang menyatukan hubunganhubungan yang tetap, walaupun sebenarnya kedua masyarakat tersebut hanyalah satu saja. Keduanya hanya merupakan dua wajah dari satu kenyataan yang sama, namun perlu dibedakan. Ketiga, dari perbedaan yang kedua itu muncul perbedaan yang ketiga, yang akan memberi ciri dan nama kepada kedua solidaritas itu. Ciri-ciri tipe kolektif tersebut adalah individu merupakan bagian dari masyarakat yang tidak terpisahkan, tetapi berbeda peranan dan fungsinya dalam masyarakat, namun masih tetap dalam satu kesatuan.

Berkaitan dengan perkembangan masyarakat, Durkheim melihat bahwa masyarakat berkembang dari masyarakat sederhana menuju masyarakat modern. Salah satu komponen utama masyarakat yang menjadi pusat perhatian Durkheim dalam memperhatikan perkembangan masyarakat adalah bentuk solidaritas sosialnya. Masyarakat sederhana memiliki bentuk solidaritas sosial yang berbeda dengan bentuk solidaritas sosial pada masyarakat modern. Masyarakat sederhana mengembangkan bentuk solidaritas sosial mekanik, sedangkan masyarakat modern mengembangkan bentuk solidaritas sosial organik. Jadi, berdasarkan bentuknya, solidaritas sosial masyarakat terdiri dari dua bentuk yaitu solidaritas mekanik dan organik.

\section{Solidaritas Sosial Mekanik}

Pandangan Durkheim mengenai masyarakat adalah sesuatu yang hidup, masyarakat berpikir dan bertingkah laku 
dihadapkan kepada gejala - gejala sosial atau fakta-fakta sosial yang seolah-olah berada di luar individu. Fakta sosial yang berada di luar individu memiliki kekuatan untuk memaksa. Pada awalnya, fakta sosial berasal dari pikiran atau tingkah laku individu, namun terdapat pula pikiran dan tingkah laku yang sama dari individu-individu yang lain, sehingga menjadi tingkah laku dan pikiran masyarakat, yang pada akhirnya menjadi fakta sosial. Fakta sosial yang merupakan gejala umum ini sifatnya kolektif, disebabkan oleh sesuatu yang dipaksakan pada tiap-tiap individu. $^{8}$

Dalam masyarakat, manusia hidup bersama dan berinteraksi, sehingga timbul rasa kebersamaan diantar mereka. Rasa kebersamaan ini milik masyarakat yang secara sadar menimbulkan perasaan kolektif. Selanjutnya, perasaan kolektif yang merupakan akibat (resultant) dari kebersamaan, merupakan hasil aksi dan reaksi diantara kesadaran individual. Jika setiap kesadaran individual itu menggemakan perasaan kolektif, hal itu bersumber dari dorongan khusus yang berasal dari perasaan kolektif tersebut. Pada saat solidaritas mekanik memainkan peranannya, kepribadian tiap individu boleh dikatakan lenyap, karena ia bukanlah diri indvidu lagi, melainkan hanya sekedar mahluk kolektif. Jadi masing-masing individu diserap dalam kepribadian kolektif.

Masyarakat bukanlah sekedar wadah untuk terwujudnya integrasi sosial yang akan mendukung solidaritas sosial, melainkan juga pangkal dari kesadaran kolektif dan sasaran utama dari perbuatan moral. Ciri khas solidaritas sosial mekanik adalah bahwa solidaritas itu didasarkan pada suatu tingkat homogenitas yang tinggi dalam kepercayaan,

${ }^{8}$ D. Paul.Johnson. Teori Sosiologi Klasik dan Modern, Jilid I dan II, terj.H. 183. sentimen, dan sebagainya. ${ }^{9}$ Solidaritas mekanik didasarkan pada suatu "kesadaran kolektif” bersama (collective consciousness), yang menunjuk pada totalitas kepercayaankepercayaan dan sentimen-sentimen bersama yang rata-rata ada pada warga masyarakat yang sama. $^{10}$ Argumentasi Durkheim, diantaranya pada kesadaran kolektif yang berlainan dengan dari kesadaran individual terlihat pada tingkah laku kelompok. Bilamana orang berkumpul untuk berdemonstrasi politik, huru-hara rasial atau untuk menonton sepakbola, gotong royong dan sebagainya, mereka melakukan hal-hal yang tidak mungkin mereka lakukan jika sendirian. Orang melakukan perusakan dan merampok toko-toko, menjungkirbalikan mobil, atau menunjukkan sikap kepahlawanan, kegiatan religius, semangat pengorbanan yang luar biasa, semuanya dianggap musatahil oleh yang bersangkutan.

Solidaritas mekanik tidak hanya terdiri dari ketentuan yang umum dan tidak menentu dari individu pada kelompok, kenyataannya dorongan kolektif terdapat dimana-mana, dan membawa hasil dimanamana pula. Dengan sendirinya, setiap kali dorongan itu berlangsung, maka kehendak semua orang bergerak secara spontan dan seperasaan. Terdapat daya kekuatan sosial yang hakiki yang berdasarkan atas kesamaankesamaan sosial, tujuannya untuk memelihara kesatuan sosial. Hal inilah yang diungkapkan oleh hukum bersifat represif/menekan. ${ }^{11}$ Pelanggaran yang dilakukan individu menimbulkan reaksi terhadap kesadaran kolektif, terdapat suatu penolakkan karena tidak searah dengan

\footnotetext{
${ }^{9}$ Ibid.

${ }^{10}$ Emile Durkheim. The Divisoin of Labor in Society, trans.by George Simpson. 1964. New York: Free Press. H. 79.

11 D. Paul.Johnson. Teori Sosiologi Klasik dan Modern, Jilid I dan II, terj.H. 79.
} 
tindakan kolektif. Tindakan ini dapat digambarkan, misalnya tindakan yang secara langsung mengungkapkan ketidaksamaan yang menyolok dengan orang yang melakukannya dengan tipe kolektif, atau tindakan-tindakan itu melanggar organ hati nurani umum.

\section{Solidaritas Sosial Organik}

Solidaritas organik berasal dari semakin terdiferensiasi dan kompleksitas dalam pembagian kerja yang menyertai perkembangan sosial. Durkheim merumuskan gejala pembagian kerja sebagai manifestasi dan konsekuensi perubahan dalam nilai-nilai sosial yang bersifat umum. Titik tolak perubahan tersebut berasal dari revolusi industri yang meluas dan sangat pesat dalam masyarakat. Menurutnya, perkembangan tersebut tidak menimbulkan adanya disintegrasi dalam masyarakat, melainkan dasar integrasi sosial sedang mengalami perubahan ke satu bentuk solidaritas yang baru, yaitu solidaritas organik. Bentuk ini benar-benar didasarkan pada saling ketergantungan di antara bagianbagian yang terspesialisasi. Kesadaran kolektif pada masyarakat mekanik paling kuat perkembangannya pada masyarakat sederhana, dimana semua anggota pada dasarnya memiliki kepercayaan bersama, pandangan, nilai, dan semuanya memiliki gaya hidup yang kira-kira sama. Pembagian kerja masih relatif rendah, tidak menghasilkan heterogenitas yang tinggi, karena belum pluralnya masyarakat. Lain halnya pada masyarakat organik, yang merupakan tipe masyarakat yang pluralistik, orang merasa lebih bebas. Penghargaan baru terhadap kebebasan, bakat, prestasi, dan karir individual menjadi dasar masyarakat pluralistik. Kesadaran kolektif perlahanlahan mulai hilang. Pekerjaan orang menjadi lebih terspesialisasi dan tidak sama lagi, merasa dirinya semakin berbeda dalam kepercayaan, pendapat, dan juga gaya hidup. Pengalaman orang menjadi semakin beragam, demikian pula kepercayaan, sikap, dan kesadaran pada umumnya.

Heterogenitas yang semakin beragam ini tidak menghancurkan solidaritas sosial. Sebaliknya, karena pembagian kerja semakin tinggi, individu dan kelompok dalam masyarakat merasa semakin tergantung kepada pihak lain yang berbeda pekerjaan dan spesialisasinya. Peningkatan terjadi secara bertahap, saling ketergantungan fungsional antar pelbagai bagian masyarakat yang heterogen itu mengakibatkan terjadi suatu pegeseran dalam tata nilai masyarakat, sehingga menimbulkan kesadaran individu baru. Bukan pembagian kerja yang mendahului kebangkitan individu, melainkan sebaliknya perubahan dalam diri individu, di bawah pengaruh proses sosial mengakibatkan pembagian kerja semakin terdiferensiasi. Kesadaran baru yang mendasari masyarakat modern lebih berpangkal pada individu yang mulai mengidentifikasikan dirinya dengan kelompok yang lebih terbatas dalam masyarakat dan mereka tetap mempunyai kesadaran kolektif yang terbatas pada kelompoknya saja, contohnya yang sesuai dengan pekerjaannnya saja. Corak kesadaran kolektif lebih bersifat abstrak dan universal. Mereka membentuk solidaritas dalam kelompok-kelompok kecil, yang dapat bersifat mekanik.

Terjadinya perubahan sosial yang ditandai oleh meningkatnya pembagian kerja dan kompleksitas sosial, dapat juga dilihat sebagai perkembangan evolusi model linier. Kecenderungan sejarah pada umumnya dalam masyarakat Barat adalah ke arah bertambahnya spesialisasi dan kompleksitas dalam pembagian kerja. Perkembangan ini mempunyai dua akibat penting. Pertama, dia 
merombak kesadaran kolektif yang memungkinkan berkembangnya individualitas. Kedua, dia meningkatkan solidaritas organik yang didasarkan pada saling ketergantungan fungsional. Durkheim melihat masyarakat industri kota yang modern ini sebagai perwujudan yang paling penuh dari solidaritas organik. Ikatan yang mempersatukan individu pada solidaritas mekanik adalah adanya kesadaran kolektif. Kepribadian individu diserap sebagai kepribadian kolektif sehingga individu saling menyerupai satu sama lain. Pada solidaritas organik, ditandai oleh heterogenitas dan individualitas yang semakin tinggi, bahwa individu berbeda satu sama lain. Masingmasing pribadi mempunyai ruang gerak tersendiri untuk dirinya, dimana solidaritas organik mengakui adanya kepribadian masing-masing orang. Karena sudah terspesialisasi dan bersifat individualistis, maka kesadaran kolektif semakin kurang. Integrasi sosial akan terancam jika kepentingan-kepentingan individu atau kelompok merugikan masyarakat secara keseluruhan dan kemungkinan konflik dapat terjadi. Inilah perbandingan sifat - sifat pokok dari masyarakat yang didasarkan pada solidaritas mekanik dengan solidaritas organik.

\section{Interaksi Sosial antar Umat Beragama sebagai Fakta Sosial.}

Interaksi sosial antar umat beragama di Desa Nania dapatlah dikatakan sangat bervariasi. Dapat dikatakan bahwa interaksi sosial di Desa Nania dalam berbagai bentuk juga merupakan fakta sosial menurut Durkeim.

Kerjasama yang terjadi antar umat beragama di Nania berlaku untuk sebagian orang saja dan kerjasama tersebut hanya dalam bentuk tolong menolong atau gotong royong. Tidak ada kerjasama yang lebih spesifik antar umat beragama di Nania. Kerjasama antar umat beragama di Desa Nania tidak begitu serius ditanggapi oleh para pemuka agama dan pemerintah yang seharusnya menjadi penonggak untuk mendukung kerjasama antar umat beragama di Nania. Inilah yang menjadi salah satu penyebab kurangnya kerjasama antar umat beragama di Nania. Hal ini juga kemungkinan besar terjadi karena di Nania banyak orang yang masih memegang prinsip agama masing-masing dan tidak mau bergaul dengan agama yang lain.

Interaksi antar umat beragama dalam bentuk akomodasi sangat memprihatinkan. Sebagian besar orang mempunyai keinginan untuk hidup dengan damai, yaitu beradaptasi saling toleransi dan berusaha meleburkan ketegangan antar umat Islam dan Kristen akan tetapi pada kenyataannya semua itu hanya pada tataran pikiran dan perkataan saja karena masih ada saling mencurigai diantara mereka sendiri. Di Nania memang sulit untuk melakukan tindakan akomodasi demi terciptanya kerukunan yang baik antar umat beragama karena penduduk Nania kebanyakan adalah pendatang dan inilah yang menjadi tantangan tersendiri.

Proses asimilasi masih belum benarbenar terjadi karena berdasarkan hasil penelitian yang telah diutarakan, ternyata hubungan antar umat beragama masih bersifat semu. Kehidupan antar umat beragama yang terjadi masih dipetakpetakkan karena perbedaan agama, suku dan kepentingan individu atau kelompok.

Persaingan yang terjadi di Desa Nania secara harafiah bisa dikatakan tidak ada. Akan tetapi jika kita melihat secara teliti dari hasil wawancara yang dilakukan, maka ada indikasi bahwa eksklusifisme keagamaan sangat terasa dan hal ini memberikan kemungkinan besar bahwa persaingan antar 
umat beragama itu ada. Hampir semua orang atau semua umat beragama di Desa Nania menghindari pertentangan. Tetapi hal tersebut kemungkinan besar hanya ada melalui perkataan semata karena meskipun dikatakan bahwa mereka menghindari pertentangan dan tidak pernah ada pertentangan namun mereka tetap memegang prinsip eksklusifisme agama masing-masing dan selalu terjebak dalam isu yang merugikan. Inilah kontroversi yang terjadi antar umat beragama di Desa Nania.

Konflik masih dengan mudah terjadi di antara umat yang berbeda agama di Desa Nania. Konflik ini bukan saja terlihat dengan alasan beda agama saja akan tetapi perbedaan suku juga sangat Nampak. Perbedaanperbedaan ini juga seringkali dimanfaatkan oleh pihak-pihak yang mau mendominasi Desa Nania berdasarkan kepentingan kelompok mereka.

Berdasarkan pandangan Durkheim, didapati bahwa orang tidak bisa langsung mengamati kelompok sebagai suatu benda fisik; orang mengambil kesimpulan mengenai eksistensinya dengan mengamati kegiatan dan interaksi individu dengan sesamanya dalam waktu tertentu atau dengan belajar dari individu-individu yang terlibat, yang menerima kelompok itu sebagai sesuatu yang riil dan berhubungan dengan kelompok itu.

Untuk membuktikan gejala-gejala sosial itu berbeda dengan gejala yang benarbenar individual, Durkheim mengemukakan dengan tegas tidak karakteristik yang berbeda dan karakteristik ini disebut oleh Durkheim sebagai karakteristik fakta sosial. Pertama, gejala sosial bersifat eksternal terhadap individu. Setelah memberikan pembuktian mengenai fakta sosial (bahasa, sistem moneter, norma-norma profesional dan lainlain), Durkheim menegaskan bahwa "ini merupakan cara bertindak, berfikir dan berperasaan yang memperlihatkan sifat patut dilihat sebagai sesuatu yang berada di luar kesadaran individu". Kedua, bahwa fakta sosial itu memaksa individu. Jelas bagi Durkheim bahwa individu dipaksa, dibimbing, diyakinkan, didorong atau dengan cara tertentu dipengaruhi oleh berbagai tipe fakta sosial dalam lingkungan sosialnya. Seperti yang Durkheim katakana "tipe-tipe perilaku atau berfikir ini mempunyai kekuatan memaksa yang karenanya mereka memaksa individu terlepas dari kemauan individu itu sendiri”. Ini tidak berarti bahwa individu itu harus mengalami paksaan fakta sosial dengan cara yang negatif atau membatasi seperti memaksa seorang anak berperilaku yang bertentangan dengan kemauannya. Karakteristik fakta sosial yang ketiga, adalah bahwa fakta itu bersifat umum atau tersebar secara meluas dalam satu masyarakat. Dengan kata lain, fakta sosial itu merupakan milik bersama, bukan sifat individu perorangan. Sifat umumnya ini bukan sekedar hasil dari penjumlahan beberapa fakta individu. Fakta sosial benarbenar bersifat kolektif dan pengaruhnya terhadap individu merupakan hasil dari sifat kolektifnya ini. Durkheim ingin menegakkan pentingnya tingkat sosial daripada menarik kenyataan sosial dari karakteristik individu.

Dengan demikian, fakta sosial meliputi gejala seperti norma, ideal moral, kepercayaan, kebiasaan, pola berpikir, perasaan dan pendapat umum. Durkheim menggunakan istilah "representatif kolektif" untuk menunjukkan gejala ini apabila mereka dimiliki bersama oleh anggota-anggota suatu masyarakat. Durkheim juga mengatakan bahwa fakta sosial harus dijelaskan dalam hubungannya dengan fakta sosial lainnya. Ini adalah asas pokok yang mutlak.

Melihat teori Durkheim tersebut, maka jika dihubungkan dengan temuan yang didapati maka sangat jelas bahwa fakta sosial 
yang terjadi di Desa Nania adalah fakta interaksi sosial antar umat beragama yang mana, masyarakat Desa Nania (individuindividu) memiliki kesadaran historis terhadap agama mereka masing-masing yang sangat kental. Pemeluk-pemeluk agama di Desa Nania lebih mengarah bukan saja kepada kepentingan pribadi mereka tetapi juga kepada kepentingan agama masingmasing, bukan kepentingan bersama. Hal ini terjadi karena "representatif kolektif" yang dimiliki oleh warga Nania hanya baru terbatas pada dimensi agama mereka masingmasing.

Durkheim mengatakan bahwa fakta sosial yang merupakan gejala umum ini sifatnya kolektif, disebabkan oleh sesuatu yang dipaksakan pada tiap-tiap individu. Fakta sosial yang terjadi di Nania, membuat para pemeluk agama-agama di Desa Nania terjebak dalam ranah atau dimensi agama mereka masing-masing sehingga solidaritas sosial yang terbentuk hanya mengalami kekuatan pada pemeluk agama yang homogen. Ini merupakan ciri khas solidaritas sosial mekanik yaitu solidaritas yang didasarkan pada suatu tingkat homogenitas yang tinggi dalam kepercayaan, sentiment dan sebagainya. Dengan demikian, masyarakat Desa Nania memiliki solidaritas mekanik didasarkan pada suatu "kesadaran kolektif" bersama (collective consciousness), yang menunjuk pada totalitas kepercayaankepercayaan dan sentimen-sentimen bersama yang rata-rata ada pada pemeluk masingmasing agama terhadap agama mereka masing-masing.

\section{Penutup}

Interaksi sosial antarumat beragama di Desa Nania, pasca konflik memperlihatkan bahwa adan kesenjangan antar individu. Interaksi yang tercipta masih sebatas pada orang-orang yang memiliki kesamaan identitas. Masih terdapat segregasi relasi dan interaksi antar identitas, secara khusus identitas keagamaan.

Dalam kaitan dengan itu, maka dapat disimpulkan bahwa interaksi sosial antarumat beragama di Desa Nania adalah interaksi sosial yang bersifat semu karena fakta sosial menunjukkan bahwa solidaritas yang terragamjalin pada masyarakat Desa Nania hanyalah solidaritas mekanik yang masih terjebak dalam agama mereka masingmasing dan bukan pada solidaritas hubungan antarumat beragama yang ada di Desa Nania.

\section{Daftar Pustaka}

Boeree, George C. Psikologi Sosial. 2010. Jogjakarta: Prismas Sophie.

Drajat C.W. Pedidikan Kesejahteraan Keluarga. 1997. Jakarta: Depdikbud.

Durkheim Emile. The Rules of Sociological Method, trans.by Sarah A. Solovay and John H. Muller and ed.by Gearge E.G. Catlin. 1964. New York: Free Press.

Durkheim Emile. The Divisoin of Labor in Society, trans.by George Simpson. 1964. New York: Free Press.

Johnson D. Paul. Teori Sosiologi Klasik dan Modern, Jilid I dan II, terj. Robert M.Z. 1964. Lawang, Jakarta: Gramedia.

Lauer H. Robert, Perspektif tentang Perubahan Sosial, 2003, Jakarta: Rineka Cipta.

Sztompka Piotr, Sosiologi Perubahan Sosial, 2007, Jakarta: Prenada.

Kasnawi Tahir, Materi Kuliah Matrikulasi Teori Sosiologi Klasik Prodi S3 Sosiologi Pascasarjana UNM, 2004. Makasar. 